\title{
PEMBELAJARAN MENULIS DALAM GAMITAN PENDIDIKAN KARAKTER
}

Yunus Abidin

Abstrak

Pembelajaran menulis haruslah ditafsirkan sebagai sebuah proses yang ditujukan untuk mengembangkan serangkaian aktivitas siswa dalam rangka menghasilkan sebuah tulisan di bawah bimbingan, arahan, dan motivasi guru. Sejalan dengan definisi ini, pembelajaran menulis seyogyanya dikembangkan melalui beberapa tahapan proses menulis sehingga siswa benar-benar mampu menulis sesuai dengan tahapan proses yang jelas. Di sisi lain, guru juga harus membekali siswa dengan berbagai strategi menulis pada setiap tahapan aktivitas menulis yang dilakukan siswa. Melalui kolaborasi peran guru dan siswa ini, pembelajaran menulis diyakini akan mencapai hasil yang memuaskan. Tanpa peran kolaborasi ini, kemampuan siswa dalam menulis tidak akan berkembang dan tetap akan rendah.

Dalam prosesnya, pembelajaran menulis hendaknya diarahkan pada upaya membina kemampuan siswa untuk menulis berbagai genre tulisan untuk berbagai tujuan, berbagai sasaran baca, dan berbagai konteks sosial budaya. Sejalan dengan tuntutan ini, pembelajaran menulis selayaknya dikemas melalui penciptaan sejumlah aktivitas-aktivitas aktif kreatif yang harus dilakukan siswa selama pembelajaran. Aktivitas aktif kreatif ini juga jangan hanya yang bersifat mereproduksi tulisan melainkan harus lebih terarah pada proses produksi tulisan yang asli dan memiliki daya kreativitas yang tinggi.

\section{Kata Kunci: Pembelajaran Menulis, Pendidikan Karakter, Kemampuan Menulis}

\section{A. Latar Belakang Masalah}

Pembelajaran menulis sampai saat ini masih menjadi bahan penelitian

yang digemari. Kondisi ini sejalan dengan kenyataan bahwa pembelajaran menulis masih menyisakan sejumlah masalah serius. Salah satu masalah serius tersebut adalah rendahnya kemampuan siswa dalam menulis. Berbagai penelitian menunjukkan bahwa kemampuan menulis sejak tingkat sekolah dasar hingga perguruan tinggi masih memprihatinkan. Sejalan dengan kenyataan ini, seorang sastra terkemuka negeri ini mengatakan bahwa bangsa Indonesia rabun membaca dan lumpuh menulis.

Pernyataan di atas tentu saja tidaklah berlebihan. Rata-rata siswa sekolah dasar sampai kelas enam belum mampu menulis secara mandiri dengan hasil yang memuaskan. Kondisi ini terjadi pula sekolah menengah bahkan perguruan tinggi. Hal yang paling menakutkan adalah kenyataan bahwa kemampuan mahasiswa dalam menulis makalah sangat rendah dan bahkan cenderung plagiat dengan 
mencuplik berbagai materi secara bebas dari internet tanpa mencantumkan sumber kutipan. Sekaitan dengan kenyataan ini, pembelajaran menulis masih memiliki nilai merah dalam pembelajaran bahasa.

Rendahnya kemampuan siswa dalam menulis disebabkan oleh berbagai faktor. Salah satu faktor yang dominan adalah rendahnya peran guru dalam membina siswa agar terampil menulis. Pembelajaran menulis yang seharusnya membina para siswa untuk berlatih mengemukakan gagasan masih belum secara optimal dikembangkan dan bahkan dianggap sebagai pembelajaran yang menyenangkan bagi guru sebab selama siswa menulis guru bisa bersantai di dalam ruang kelas bahkan meninggalkan ruang kelas untuk berbicara dengan guru lain di ruang guru. Kondisi ini diperparah dengan kebiasaan guru tidak memberikan penilaian secara tepat kepada siswa dalam hal kemampuan menulis. Hasil tulisan siswa terkadang hanya dinilai dari jumlah paragraf yang dihasilkan, kerapian tulisan, dan faktor lain yang tidak esensial. Penilaian yang demikian jelas bukanlah sebuah penilaian yang berfungsi membangun kemampuan menulis siswa bahkan sebaliknya bisa menghancurkan kemampuan menulis siswa yang sesungguhnya.

Kondisi lain yang menyebabkan kemampuan siswa dalam menulis masih rendah adalah kurangnya sentuhan guru dalam hal memberikan berbagai strategi menulis yang tepat. Guru terkesan menganggap menulis merupakan pekerjaan yang sulit sehingga jika siswa sudah menulis walaupun hasilnya belum bagus sudah dianggap memenuhi kompetensi yang diharapkan tanpa memberikan batuan langsung kepada siswa untuk mengembangkan kemampuannya menulis. Di sisi lain, ada pula yang menganggap menulis adalah pekerjaan yang mudah sehingga tanpa bimbingan pun siswa sudah bisa menulis. Kondisi ini tentu saja tidaklah tepat sebab seharusnya seorang guru harus membimbing siswanya menulis setahap demi setahap sesuai dengan proses menulis itu sendiri. Melalui pembelajaran yang demikian siswa akan mengetahui secara tepat kelemahannya selama menulis dan atas dasar ini siswa akan memperbaikinya guna menghasilkan tulisan yang lebih baik.

Kondisi lain yang menyebabkan siswa kurang mampu menulis adalah penggunaan pendekatan menulis yang kurang tepat. Sampai saat ini masih banyak para guru mengajarkan menulis dengan menggunakan pendekatan gramatis sebagai pendekatan utamanya. Penggunaan pendekatan ini sebagai pendekatan utama menyebabkan siswa enggan menulis sebab ia harus terlebih dahulu banyak belajar tentang tata bahasa. Dalam praktiknya, guru yang menggunakan pendekatan ini secara dominan akan cenderung memberikan penguatan tata bahasa dalam menulis dibanding dengan bagaimana siswa mengemukakan 
gagasan dalam menulis agar lebih baik. Akhirnya, siswa mungkin pandai bertata bahasa namun lemah dalam isi.

Pembelajaran lain yang masih kerap dijumpai adalah pembelajaran menulis yang berpola pikir, tulis, kontrol. Pola pembelajaran menulis seperti ini seperti tidaklah salah. Namun dalam kenyataannya banyak banyak siswa yang terlalu banyak berpikir sehingga ia tidaklah sempat menulis. Kondisi ini sejalan dengan banyak siswa yang sulit sekali menentukan kalimat pertama dalam sebuah karangan. Lebih jauh tulisan tidak pernah selesai karena banyak pemikiran yang rumit sehingga baru menulis satu dua paragraf, siswa merasa tulisannya belum layak sehingga mereka memilih menulis lagi dari awal. Akhirnya tulisan tersebut tidak bisa diselesaikan siswa. Kondisi lain adalah tulisan yang dihasilkan berputar-putar tidak jelas sebab mereka takut ke luar dari tema yang ditentukan guru. Melihat kenyataan ini, pola pembelajaran menulis pikir, tulis, kontrol, seyogyanya diganti dengan pola tulis, pikir, dan kontrol. Tulis saja, apa saja, di mana saja, kapan saja, barulah revisi dengan berpikir, dan edit melalui kontrol ejaan dan pedoman teknis penulisan lainnya.

Melihat kondisi di atas, ekologi pembelajaran menulis di sekolah harus segara diperbaiki. Pembelajaran menulis seyogyanya dikembalikan pada orientasi yang benar yakni siswa mencintai menulis, bisa menulis, dan kreatif menulis. Guna mencapai orientasi ini, diperlukan berbagai perubahan dalam pola pembelajaran menulis. Dalam hal ini, guru harus mampu memilih metode menulis yang tepat, menggunakan berbagai media yang mendukung, dan meluruskan niatnya bahwa ketika mengajar menulis, hal yang harus dilakukan siswa adalah menulis bukan mengetahui teori tentang menulis. Permasalahannya sekarang adalah bagaimana melaksanakan pembelajaran menulis yang mampu mengembangkan kemampuan siswa menulis sekaligus membangun karakter para siswa? Sejalan dengan rumusan masalah ini, tulisan ini bertujuan untuk memaparkan proses pembelajaran menulis yang mampu mengembangkan kemampuan siswa menulis sekaligus membangun karakter para siswa.

\section{B. Konsep Dasar Pembelajaran Menulis}

Menulis dapat didefinisikan melalui berbagai sudut pandang. Dalam sudut pandang yang paling sederhana, menulis dapat diartikan sebagai proses menghasilkan lambang bunyi. Pengertian semacam menulis ini dikenal sebagai menulis permulaan. Pada tahap selanjutnya menulis dapat bersifat lebih kompleks. Menulis pada dasarnya adalah proses untuk mengemukakan ide dan gagasan dalam bahasa tulis. Oleh sebab itu, Akhadiah (1999) memandang menulis adalah sebuah proses, yaitu proses penuangan gagasan atau ide ke dalam bahasa tulis yang dalam praktiknya proses menulis diwujudkan dalam beberapa tahapan 
yang merupakan satu sistem yang utuh. Lebih lanjut, Gie (2002) menyatakan bahwa menulis memiliki kesamaan makna dengan mengarang yaitu segenap kegiatan seseorang mengungkapkan gagasan dan menyampaikannya melalui bahasa tulis kepada pembaca untuk dipahami. Dari definisi ini dapat dikemukakan bahwa menulis adalah sebuah proses berkomunikasi secara tidak langsung antara penulis dengan pembacanya. Sebuah tulisan dibuat untuk dipahami maksud dan tujuannya sehingga proses yang dilakukan penulis tidaklah sia-sia.

Dalam sudut pandang lain, menulis dapat pula dikatakan sebagai kegiatan mereaksi artinya menulis adalah proses mengemukakan pendapat atas dasar masukan yang diperoleh penulis dari berbagai sumber ide yang tersedia. Sumber ide bisa saja adalah segala objek yang yang mampu merangsang penulis untuk menulis termasuk di dalamnya tulisan lain yang telah dihasilkan orang lain. Dalam kaitannya tulisan hasil orang lain yang mendorong seseorang menulis, tulisan yang dihasilkannya dikenal dengan istilah tulisan reproduksi. Menulis juga didefinisikan sebagai aktivitas menghasilkan pesan dalam dimensi sosial dan untuk tujuan tertentu. Menulis dalam hal ini ditafsirkan sebagai aktivitas membuat makna yang berhubungan dengan pengembangan kemampuan individu dalam memahami konteks sosial budaya tempat tulisan tersebut dibuat. Menulis dengan kata lain adalah kemampuan memahami konteks sosial budaya masyarakat. 


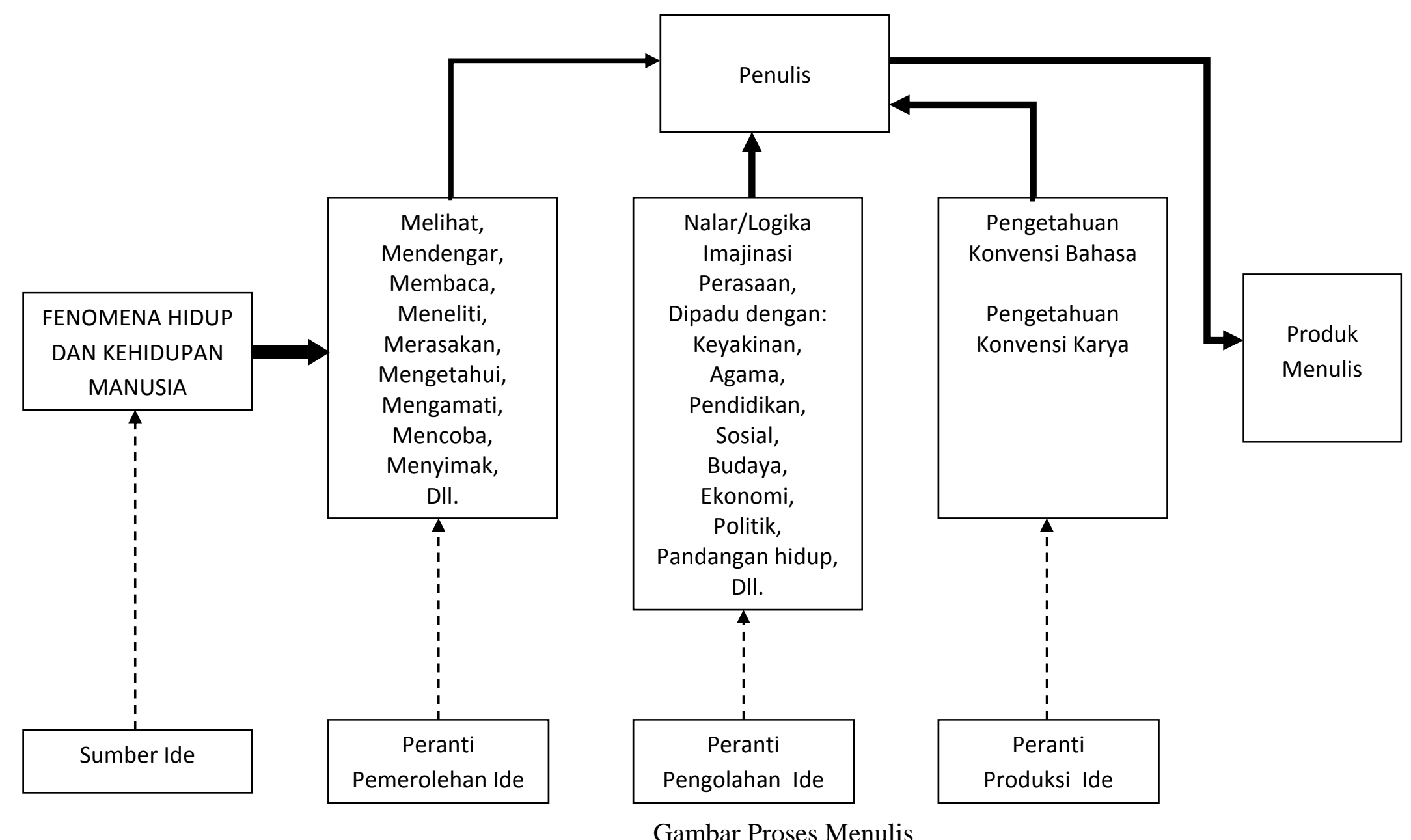


Berdasarkan gambar di atas, menulis pada dasarnya adalah sebuah proses. Hal ini sesuai dengan kenyataan bahwa produk menulis yang dihasilkan seorang penulis diproduksi melalui berbagai tahapan. Tahapan tersebut terbentang dari tahap pemerolehan ide, pengolahan, ide hingga pemroduksian ide. Pada tahap pemerolehan ide, penulis mendayagunakan kepekaannya untuk mereaksi berbagai fenomena hidup dan kehidupan manusia yang diketahuinya melalui berbagai peranti pemerolehan ide. Sejalan dengan hal tersebut, kemampuan menulis diawali oleh kemampuan seseorang melatih daya tanggapnya terhadap sumber ide. Oleh karenanya, untuk menjadi seorang penulis, seseorang harus senantiasa mengembangkan keterampilan daya tanggap sasmitanya. Bertemali dengan proses ini, menulis dapat dikatakan sebagai proses mereaksi sebuah fenomena melalui produksi bahasa tulis.

Tahap kedua dalam proses menulis adalah tahapan pengolahan ide. Pada tahap ini penulis akan mendayagunakan beberapa kemampuan meliputi kemampuan berpikir, kemampuan berasa, dan kemampuan berimajinasi. Penggunaan jenis kemampuan ini akan sangat bergantung pada tujuan tulisan yang akan diproduksi. Kemampuan imajinasi misalnya, akan sangat diberdayakan untuk menulis sebuah karya yang bertujuan untuk menghibur atau memberikan daya sugesti kepada para pembaca. Kemampuan berpikir digunakan pada setiap tujuan penulisan. Oleh karenanya, banyak para ahli yang memandang bahwa menulis pada dasarnya adalah proses berpikir yakni proses yang melibatkan kemampuan berpikir untuk menghasilkan pesan tertulis bagi para pembacanya. Demikian pula kemampuan berasa akan digunakan secara optimal ketika seorang penulis bermaksud memproduksi sebuah tulisan yang bertujuan untuk memengaruhi orang lain dengan mengoptimalkan peranti daya bujuk berupa perasaan penulis.

Pada tahap pengolahan ide, selain mendayagunakan ketiga peranti kemampuan tadi, penulis juga akan menggunakan kemampuannya berkontemplasi guna memberikan makna dan nilai pada tulisan yang diproduksinya. Kemampuan berkontemplasi ini akan sangat berhubungan dengan latar belakang penulis yang antara lain keyakinan, pandangan hidup, agama, tata nilai dan norma sosial budaya, latar belakang pendidikan, dan pandangan politik penulis serta berbagai unsur eksternal lainnya yang bersentuhan dengan penulis. Hasil dari kegiatan kontemplasi ini adalah 
bahwa sebuah tulisan akan memiliki muatan filosofis, religius, dan nilai makna kehidupan lainnya yang sangat berguna bagi pembaca. Sejalan dengan proses ini, menulis juga dapat dikatakan sebagai proses kontemplasi yang dilakukan seseorang untuk menghasilkan gagasan yang bermanfaat dan bernilai bagi pembacanya.

Tahap ketiga yang harus dilakukan penulis dalam proses menulis adalah tahapan produksi ide. Pada tahap ini penulis akan menggunakan peranti produksi ide yakni pengetahuan bahasa dan pengetahuan konvensi karya. Pengetahuan bahasa merupakan peranti utama yang digunakan oleh penulis dalam mengemas gagasan yang telah diolahnya. Melalui penggunaan pengetahuan atau kemampuan berbahasa ini sebuah ide dikemas sesuai dengan tujuannya serta memenuhi asas ketatabahasaan yang berterima di kalangan pembacanya. Pengetahuan konvensi karya di sisi lain akan digunakan untuk mengemas gagasan agar sesuai dengan genre tulisan yang akan dihasilkan. Dalam menulis puisi misalnya, seorang penulis akan menggunakan pengetahuannya tentang bahasa khususnya gaya bahasa dalam mengemas idenya sehingga tulisannya akan mencerminkan penggunaan bahasa yang khas, padat, dan bermakna. Selain itu, ide tersebut selanjutnya akan dikemas dengan menggunakan pengetahuannya tentang konvensi puisi sehingga tulisan yang diproduksinya dapat berterima sebagai sebuah puisi. Gambaran penggunaan peranti produksi ini juga sama halnya jika seorang penulis bermaksud menghasilkan berbagai macam tulisan pada genre-genre yang lain.

Setelah ketiga proses tersebut diselesaikan penulis akan dihasilkan produk menulis yakni tulisan itu sendiri. Produk menulis yang dihasilkan akan sangat beragam baik dari segi tujuan, genre, maupun sasarannya. Namun demikian, seluruh produk menulis ini pada dasarnya bertujuan untuk menjalin komunikasi antara penulis dengan pembacanya. Atas dasar inilah, wajar jika Gie (2002) memandang menulis merupakan kegiatan menjalin komunikasi tidak langsung dengan pembaca melalui penggunaan media tulisan yang dihasilkan. Berdasarkan sudut pandang teknis menulis Tomkins dan Hosskinson (1991) menguraikan proses menulis menjadi lima tahap yakni: tahap pramenulis, tahap pembuatan draf, tahap editing, tahap revising, dan tahap publikasi. 
Bertemali dengan pengertian menulis sebagai proses di atas, pembelajaran menulis haruslah ditafsirkan sebagai sebuah proses yang ditujukan untuk mengembangkan serangkaian aktivitas siswa dalam rangka menghasilkan sebuah tulisan di bawah bimbingan, arahan, dan motivasi guru. Sejalan dengan definisi ini, pembelajaran menulis seyogyanya dikembangkan melalui beberapa tahapan proses menulis sehingga siswa benar-benar mampu menulis sesuai dengan tahapan proses yang jelas. Di sisi lain, guru juga harus membekali siswa dengan berbagai strategi menulis pada setiap tahapan aktivitas menulis yang dilakukan siswa. Melalui kolaborasi peran guru dan siswa ini, pembelajaran menulis diyakini akan mencapai hasil yang memuaskan. Tanpa peran kolaborasi ini, kemampuan siswa dalam menulis tidak akan berkembang dan tetap akan rendah.

\section{Orientasi Pembelajaran Menulis}

Secara esensial minimalnya ada tiga tujuan utama pembelajaran menulis yang yang dilaksanakan para guru di sekolah. Ketiga tujuan tersebut adalah (1) menumbuhkan kecintaan menulis pada diri siswa, (2) mengembangkan kemampuan siswa menulis, (3) membina jiwa kreativitas para siswa untuk menulis. Ketiga tujuan ini merupakan tujuan minimal yang harus dicapai para siswa melalui proses pembelajaran menulis yang dialaminya (Abidin, 2012).

Tujuan pertama pembelajaran menulis adalah menumbuhkan kecintaan menulis pada diri siswa. Tujuan ini menjadi sangat penting sebab mencitai menulis adalah modal awal bagi siswa agar mau menulis sehingga ia akan menjadi seorang yang terbiasa menulis. Hal ini sejalan dengan hakikat menulis sebagai keterampilan sehingga untuk dapat menguasai menulis sebagai sebuah keterampilan intensitas dalam menulis merupakan faktor kuncinya. Dengan kata lain kemampuan menulis sangat dipengaruhi intensitas menulis. Semakin sering seseorang menulis diyakini akan semakin baik pula hasil tulisannya. Guna mencapai intensitas menulis yang tinggi ini, para siswa tentu saja harus terlebih dahulu mencintai menulis.

Modal dasar mencitai menulis diyakini akan mendorong siswa mampu menulis. Kemampuan siswa menulis ini merupakan tujuan pembelajaran menulis yang kedua. Kemampuan menulis yang dimaksud adalah kemampuan siswa memproduksi berbagai ragam tulisan untuk 
berbagai kepentingan, sasaran, dan konteks sosial budaya. Berdasarkan tujuan ini, pembelajaran menulis harus diarahkan agar mampu membekali siswa berbagai strategi menulis, macam-macam tulisan, serta sarana publikasi tulisan. Melalui pemberian strategi menulis, siswa akan terhindari dari kesulitan selama menulis. Pengenalan macam-macam tulisan akan membekali siswa tentang bagaimana cara menulis berdasarkan genre yang harus dihasilkan. Pengenalan sarana publikasi sangat penting agar siswa merasa tulisannya diapresiasi sehingga akan timbul keinginannya untuk tetap menulis serta meningkatkan kemampuannya menulis sebab mendapatkan banyak umpan balik atas tulisan yang telah dipublikasikannya.

Tujuan terakhir adalah agar siswa mampu menulis secara kreatif. Tujuan ini menghendaki agar siswa mampu menjadikan menulis bukan sekadar sebagai kompetensi yang harus dikuasai selama mengikuti pembelajaran, melainkan agar siswa mampu memanfaatkan menulis sebagai sebuah aktivitas yang mendatangkan berbagai keuntungan baik keuntungan yang bersifat psikologis, ekonomis, maupun sosiologis. Bertemali dengan hal ini, menulis seyogyanya menjadi sebuah kebutuhan bagi siswa dalam rangka mengekspresikan diri sehingga terbebas dari beban-beban psikologis. Jika siswa telah mencapai taraf ini, menulis bukanlah hal yang menakutkan melainkan hal yang harus dilakukan agar ia merasa tenang dan termotivasi dalam hidup. Dalam pandangan ekonomis menulis juga memberikan kesempatan pada siswa untuk mendapatkan berbagai keuntungan melalui menulis. Siswa yang telah mampu kreatif menulis dapat memublikasikan tulisannya dalam berbagai media yang akan berdampak secara finansial bagi dirinya. Lebih jauh, publikasi ini akan meningkatkan prestisenya di masyarakat sehingga secara sosiologis ia akan terkenal di masyarakat. Guna mencapai tujuan ini, jelaslah pembelajaran menulis harus diorientasikan agar siswa bukan hanya bisa menulis melainkan kreatif menulis.

Selain ketiga tujuan di atas, pembelajaran menulis pun seyogyanya mampu mengembangkan karakter siswa. Berkenaan dengan tujuan ini, pembelajaran menulis harus dilakukan melalui penyediaan serangkaian aktivitas yang menuntut siswa mengunjukkerjakan karakter dirinya selama pembelajaran. Melalui berbagai aktivitas yang menantang diharapkan siswa mampu aktif bekerja keras sehingga secara tidak sadar ia telah berupaya pula membangun karakter positif selama pembelajaran. 
Bertemali dengan tujuan pembelajaran menulis di atas, ada beberapa konsekuensi yang harus dilakukan guru selama pembelajaran menulis. Beberapa konsekuensi tersebut adalah sebagai berikut.

1. Guru hendaknya menguasai berbagai strategi menulis, konsep jenis-jenis tulisan, dan media publikasi bagi wahana tulisan yang dihasilkan siswa.

2. Guru hendaknya terbiasa menulis agar ia mampu menjadi model menulis bagi para siswanya.

3. Selama pembelajaran menulis, guru hendaknya senantiasa melatih seluruh kemampuan siswa sejak dari tahap penangkapan ide sampai tahap penyampaian ide.

4. Selama pembelajaran menulis, guru hendaknya senantiasa memberikan bimbingan, arahan, dan motivasi agar siswa terpacu untuk mampu menulis.

5. Pembelajaran menulis hendaknya tidak dibatasi ruang kelas melainkan dilakukan di mana pun agar siswa bisa terfokus menulis.

\section{Prinsip Pembelajaran Menulis}

Dalam rangka mewujudkan pembelajaran menulis yang harmonis, bermutu, dan bermartabat, harus diketahui terlebih dahulu prinsip-prinsip pembelajaran menulis. Diharapkan prinsip-prinsip ini akan menjadi pedoman bagi guru dalam melaksanakan pembelajaran menulis sehingga mencapai tujuan yang dicita-citakan. Prinsip-prinsip pembelajaran menulis tersebut dikemukakan Brown (2001) sebagai berikut.

1. Pembelajaran menulis harus merupakan pelaksanaan praktik menulis yang baik. Dalam hal ini guru harus membiasakan siswa menulis dengan mempertimbangkan tujuan, memperhatikan pembaca, menyediakan waktu yang cukup untuk menulis, menerapkan teknik dan strategi menulis yang tepat, dan melaksanakan menulis sesuai dengan tahapan penulisan.

2. Pembelajaran menulis harus dilaksanakan dengan menyeimbangkan antara proses dan produk.

3. Pembelajaran menulis harus memperhitungkan latar belakang budaya literasi siswa. 
4. Pembelajaran menulis harus senantiasa dilaksanakan dengan menggunakan pendekatan whole language khususnya menggabungkan antara membaca dan menulis.

5. Pembelajaran menulis harus dilaksanakan dengan menerapkan kegiatan menulis otentik seoptimal mungkin. Menulis otentik adalah menulis yang bermakna bagi siswa sekaligus dibutuhkan siswa dalam kehidupannya sehari-hari

6. Pembelajaran menulis harus dilaksanakan dalam tiga tahapan yakni tahap pramenulis, tahap menulis, dan tahap pascamenulis.

7. Gunakan strategi pembelajaran menulis interaktif, koperatif, dan kolaboratif.

8. Gunakan strategi yang tepat untuk mengoreksi kesalahan siswa dalam menulis.

9. Pembelajaran menulis harus dilakukan dengan terlebih dahulu menjelaskan aturan penulisan misalnya jenis tulisan, konvensi tulisan, dan retorika menulis yang bagaimana yang harus digunakan siswa selama tugas menulis.

Berdasarkan beberapa prinsip yang dikemukakan Brown di atas, jelaslah bahwa pembelajaran menulis harus dilakukan guru dengan sebaik mungkin dan seoptimal mungkin. Pembelajaran menulis haruslah menekankan proses menulis yang sesungguhnya sehingga pembelajaran menulis tidak hanya sekadar menekankan pada produk menulis. Pembelajaran menulis pun harus dilakukan guru dengan mengaitkannya dengan keterampilan berbahasa yang lain khususnya membaca. Tulisan yang dibuat siswa haruslah tulisan otentik yang bermakna dan bermanfaat bagi siswa. Strategi pembelajaran interaktif, kolaboratif, dan kooperatif merupakan strategi yang memungkinkan siswa menulis secara tepat. Selanjutnya guru harus pula memberikan pengetahuan yang memadai tentang jenis tulisan, konvensi penulisan, retorika dalam menulis sehingga siswa mampu menulis sesuai dengan tujuan. Terakhir peran guru dalam memberikan umpan balik pada siswa sangat diperlukan. Guna melaksanakan peran ini guru harus memanfaatkan penilaian otentik atau penilaian formatif dalam pembelajaran menulis.

Selain beberapa prinsip di atas, masih terdapat beberapa prinsip lain lain pembelajaran menulis. Beberapa prinsip tersebut adalah sebagai berikut. 
1. Pembelajaran menulis hendaknya menerapkan pola tulis, pikir, kontrol, agar siswa terbiasa menulis dan mau menulis.

2. Pembelajaran menulis hendaknya memiliki tujuan jangka panjang agar siswa kreatif menulis.

3. Pembelajaran menulis hendaknya diikuti dengan penyediaan sarana publikasi tulisan sehingga siswa lebih termotivasi menulis.

4. Pembelajaran menulis hendaknya disertai bentuk penilaian formatif yang tepat sehingga guru dapat secara tepat sasaran memperbaiki kelemahan siswa dalam menulis.

5. Pembelajaran menulis hendaknya menekankan kreativitas siswa dalam menulis meliputi kemampuannya menulis secara orisinal, lancar, luwes, dan bermanfaat.

6. Pembelajaran menulis hendaknya dilengkapi dengan pemanfaatan teknologi dalam menulis.

Bertemali dengan prinsip-prinsip pembelajaran menulis di atas, guru harus benar-benar meningkatkan kompetensinya dalam hal menulis. Kompetensi yang dimaksud adalah kemampuannya menulis secara langsung dan pengetahuannya tentang teori menulis. Selain itu, guru harus secara kreatif menciptakan proses pembelajaran menulis yang mendorong motivasi intrinsik siswa berkembang sehingga siswa terpacu untuk mau dan bisa menulis. Yang tak kalah penting adalah guru harus menerapkan proses pembelajaran menulis secara tepat berbasis proses menulis yang sesungguhnya.

\section{E. Prosedur Pembelajaran Menulis}

Sebagaimana pembelajaran keterampilan berbahasa yang lain, prosedur pembelajaran menulis terdiri atas tiga tahapan yakni tahap pramenulis, tahap menulis, dan tahap pascamenulis. Tahap pramenulis adalah tahapan yang dilakukan siswa untuk mempersiapkan diri dalam menulis. Tahap menulis adalah tahapan tempat siswa secara langsung melaksanakan praktik menulis. Tahap pascamenulis adalah tahapan yang memberikan kesempatan bagi siswa untuk memperbaiki hasil tulisannya dan akhirnya memberikan kesempatan bagi siswa untuk memublikasikan produk tulisan yang dihasilkannya. Ketiga tahapan tersebut selanjutnya diuraikan sebagai berikut. 
Brown (2001) mengemukakan bahwa pada tahap pramenulis siswa dapat melakukan berbagai aktivitas menulis. Beberapa aktivitas dimaksud adalah sebagai berikut.

1. Membaca dan menyimak untuk menulis. Siswa membaca atau menyimak secara ekstensif sebuah teks guna beroleh ide untuk menulis.

2. Curah pendapat. Siswa mencurahkan pendapatnya tentang sebuah objek yang akan dijadikan bahan tulisannya.

3. Mendiskusikan ide. Siswa bersama teman kelompoknya membicarakan tentang sebuah ide yang akan dikembangkan.

4. Siswa menjawab pertanyaan pancingan guru sebagai dasar ia menulis.

5. Melaksanakan penelitian ke luar ruangan. Siswa melakukan eksplorasi di luar kelas untuk menemukan sumber ide.

6. Siswa atau guru memberikan beberapa kata kunci sebagai bahan dasar menulis.

Sejalan dengan apa yang dikemukakan Brown, Sorenson (2010) mengemukakan beberapa alternatif aktivitas pramenulis sebagai berikut.

1. Mengumpulkan pikiran informasi;

a. membaca beragam bacaan untuk mengumpulkan informasi

b. diskusi kelompok

c. wawancara terhadap narasumber

d. refleksi diri

e. membaca jurnal atau catatan harian yang telah dibuat

f. curah pendapat

g. membuat daftar ide

h. membuat organisasi ide melalui grafik

i. mengingat pengalaman sehari-hari yang didengar dan dilihat

j. mengingat pengalaman sehari-hari yang dilakukan sendiri

2. Menentukan dan menamakan topik. Topik yang dipilih hendaknya adalah hal yang paling dikuasai dan paling menarik bagi siswa.

3. Membatasi subjek/ atau topik.

4. Menentukan tujuan dan maksud penulisan.

5. Menentukan pembaca.

6. Membuat kerangka karangan

Aktivitas pramenulis yang dikemukakan Sorenson (2010) ini lebih memperluas kesempatan kepada siswa dalam rangka menentukan ide apa 
yang akan ditulis. Sebelum menulis siswa dapat melakukan berbagai kegiatan mengumpulkan ide baik berdasarkan pengalaman, penelitian, membaca dan menyimak, wawancara, dan curah pendapat. Selain itu aktivitas pramenulis yang tidak kalah penting dilakukan siswa adalah menentukan maksud dan tujuan menulis yang akan berhubungan dengan jenis tulisan yang akan dibuat serta sasaran tulisan yang dituju. Selain itu, siswa harus pula menyusun kerangka karangan karena kerangka karangan dianggap sangat berfungsi bagi siswa untuk memandu pengembangan ide, mengekonomiskan kinerja, dan mempermudah mengakhiri dan menyisipi ide lain yang dianggap perlu.

Tahapan kedua dalam proses pembelajaran menulis adalah tahap menulis. Pada tahap ini aktivitas siswa adalah mengembangkan kerangka karangan yang telah dibuatnya. Siswa harus mengembangkan kerangka karangan tersebut dengan menggunakan kalimat dan paragraf yang baik. Dalam praktiknya tahap menulis ini dapat dilakukan secara individu, secara kolaboratif, dan atau secara kooperatif. Yang terpenting adalah bahwa seluruh siswa harus terlibat secara langsung dalam kegiatan menulis. Secara lebih mendetail, tahapan proses menulis pada tahap ini dikemukakan Sorenson (2010) sebagai berikut.

1. Mempersiapkan diri.

2. Mengikuti kerangka yang telah dibuat.

3. Menggunakan pendekatan "yo-yo" yakni menulis dan sesekali melihat kembali tahapan pramenulis untuk menentukan secara tepat ide-ide penjelas.

4. Membiarkan arus pikiran. Selama menulis jangan pernah memedulikan penggunaan ejaan, kesalahan kata, kalimat, dan paragraf, serta jangan melakukan kegiatan membaca tulisan yang belum selesai.

5. Kembangkan paragraf berdasarkan teknik pengembangan paragraf yang baik.

6. Tetaplah pada tema untuk menjaga kesatuan tulisan.

7. Abaikan untuk sementara kesalahan-kesalahan detail khusus.

8. Tulislah draf sekali jadi.

Tahap pascamenulis dapat dilakukan dengan berbagai aktivitas. Brown (2001) mengemukakan beberapa kegiatan yang dapat dilakukan siswa dalam tahap ini sebagai berikut.

1. Merevisi dan mengedit tulisan sendiri. 
2. Merevisi dan mengedit tulisan atas masukan guru.

3. Merevisi dan mengedit tulisan atas masukan teman

4. Pembacaan profesional.

5. Publikasi tulisan.

Senada dengan aktivitas di atas, Sorenson (2010) mengemukakan beberapa aktivitas pascamenulis sebagai berikut.

1. Lakukan pengecekan struktur seluruh paragraf untuk menentukan sudahkah tulisan dibagi dalam tiga kelompok besar yakni pendahuluan, isi, dan penutup.

2. Lakukan pengecekan terhadap struktur paragraf.

3. Lakukan pengecekan terhadap struktur kalimat.

4. Lakukan pengecakan bagian-bagian penting yang ditekankan dalam tulisan.

5. Lakukan pengecekan terhadap konsistensi baik isi, bahasa, ejaan, dan teknis menulis lainnya.

6. Lakukan pembacaan profesional untuk menelaah kembali penggunaan tanda baca, tata bahasa, dan isi tulisan.

7. Lakukan publikasi tulisan.

Sejalan dengan beberapa aktivitas yang dikemukakan Brown dan Sorenson, aktivitas penyuntingan dan pembacaan profesional pada tahap ini dapat dilakukan oleh siswa sendiri, dilakukan oleh temannya atau kelompok lain, dan juga dapat dilakukan oleh guru. Yang terpenting adalah bahwa seluruh koreksi yang dilakukan selanjutnya harus diperbaiki oleh siswa yang menulis sebelum karya tersebut dipublikasikan.

\section{F. Keterpaduan Pembelajaran Menulis dengan Pendidikan Karakter}

Dalam kaitannya dengan pendidikan karakter, prosedur pembelajaran menulis ini merupakan saluran pendidikan karakter. Pada masing-masing tahapan pembelajaran menulis terdapat sejumlah aktivitas yang harus dilakukan siswa. Melalui aktivitas-aktivitas inilah siswa akan secara tidak sadar menunjukkan karakter dirinya.

Pada tahap pramenulis, siswa dapat melakukan serangkaian aktivitas seperti eksplorasi fenomena untuk mendapatkan ide. Kegiatan ini akan menuntut siswa untuk mendayagunakan panca indera dan perasaannya dalam menangkap ilham atau ide dasar bagi bahan tulisannya Pada saat siswa 
melakukan kegiatan eksplorasi, ia sebenarnya sedang membiasakan diri untuk teliti, cermat, peka, antusias, tanggung jawab, kreatif, kritis, inisiatif, dan disiplin. Pada saat siswa menulis naskah secara kooperatif, siswa akan dibiasakan untuk saling menghargai, kerja sama, tanggung jawab, kreatif, kritis, inisiatif, problem solving, produktif, keuletan, kecekatan, suka mengambil risiko, dan komitmen, serta beberapa nilai karakter lainnya.

Pada tahap penyuntingan dan pembacaan profesional, siswa akan dibiasakan untuk cermat, disiplin, jujur, teliti, analitis, visioner, bertanggung jawab, perhatian, sungguh-sungguh, berorientasi pada prestasi, komitmen, keterbukaan, kerapian, ketegasan, kehati-hatian, keluwesan keantusiasan, bekerja keras,dan sejumlah nilai karakter lainnya. Pada tahap publikasi akan berkembang nilai karakter meliputi percaya diri, bangga pada diri sendiri dan kelompoknya, kreatif, berani, disiplin, sportivitas, dan amanah.

Berdasarkan uraian di atas, pembelajaran menulis dapat digunakan sebagai wahana bagi implementasi pendidikan karakter. Syarat utamanya adalah bahwa pembelajaran menulis harus dilakukan dalam gamitan pembelajaran aktif dan kreatif. Melalui aktivitas-aktivitas yang dilakukan siswa siswa akan beroleh pengetahuan, pengalaman, sekaligus pengembangan karakter. Jika selama proses pembelajaran digunakan penilaian otentik, pembudayaan karakter juga akan semakin kuat sehingga siswa benar-benar mampu mencapai prestasi belajar yang baik sekaligus berkarakter. Inilah sebenarnya implementasi pembelajaran bahasa Indonesia yang harmonis, bermutu, dan bermartabat.

\section{G. Model Pembelajaran Menulis}

Berdasarkan berbagai aktivitas yang telah dibahas pada bagian proses pembelajaran menulis, sebenarnya dapat dikembangkan berbagai metodemetode pembelajaran menulis secara kreatif. Namun demikian, pada bab ini dirasa perlu juga mengemukakan beberapa metode atau model pembelajaran menulis yang telah ada maupun yang dikreasi sendiri.

1. Model Proses Menulis

Model proses menulis merupakan model pembelajaran menulis yang paling awal dikembangkan. Hal ini sejalan dengan kenyataan bahwa model-model yang lain dikembangkan atas dasar model ini. Cox (1999) menyatakan model proses menulis pada dasarnya adalah model 
pembelajaran menulis yang menekankan aktivitas siswa menulis sesuai dengan tahapan menulis itu sendiri. Dengan demikian siswa harus mampu secara mandiri menemukan ide, mengorganisasi ide, dan reproduksi ide dalam sebuah tulisan.

2. Model Bengkel Menulis (Writing Workshop)

Bengkel menulis menulis adalah sebuah wilayah literasi tempat siswa belajar proses menulis melalui penyediaan waktu secukupnya oleh guru agar siswa secara pasti dapat merencanakan, mengorganisasikan, dan menyajikan tulisannya. (Dorn \& Soffos, 2001: 32). Tujuan utama model ini ini adalah agar siswa mampu memilih topik secara tepat dan mengembangkannya dalam berbagai jenis tulisan. Melalui kegiatan ini siswa diharapkan mampu memahami apa sebenarnya proses menulis.

Bengkel menulis pada dasarnya dikembangkan atas dasar proses menulis yakni pramenulis, pembuatan draf, revisi, editing, dan publikasi tulisan. Tahapan ini dimaksudkan agar siswa memiliki kerangka kerja yang baik untuk mengembangkan dan menyusun tugas menulisnya. Selama proses pembelajaran guru harus membimbing siswa menulis dan memberikan umpan balik atas tulisan siswa. Pada tahap akhir proses, guru harus menilai tulisan yang dibuat siswa. Melalui pola kerja ini diyakini kemampuan siswa menulis akan berkembang lebih baik.

3. Model Menulis Berbasis Genre (Genre-Based Writing)

Model menulis berbasis genre pada dasarnya model pembelajaran menulis yang menekankan pentingnya pemahaman sebuah teks sebagai bekal kegiatan menulis (Macken, et,al, 1990). Berdasarkan pengertian ini, pembelajaran menulis akan diawali dengan membekali siswa tentang bagaimana sebuah tulisan dengan genre tertentu dibuat secara tepat berdasarkan contoh atau model tulisan yang sudah jadi.

4. Model Menulis Otentik

Model menulis otentik merupakan model pembelajaran menulis yang menekankan kebebasan siswa dalam menentukan tema dan genre tulisan berdasarkan minatnya (Sundem, 2007: 34). Sejalan dengan pengertian ini, siswa dapat menentukan tema yang beragam dan jenis tulisan yang beragam. Yang terpenting adalah bahwa tulisan tersebut bermakna bagi siswa yang berarti bahwa tulisan tersebut sesuai dengan kehidupan siswa dan berguna bagi siswa. Selain itu, model ini menekankan pemberian 
bimbingan secara bervariasi pada setiap tahapan penulisan yang dirasakan sulit oleh siswa. Oleh karena itu, penggunaan penilaian otentik merupakan prasyarat mutlak bagi penerapan model ini.

\section{Model Scaffolded Writing}

Model Scaffolded Writing merupakan model pembelajaran menulis yang seluruh perencanaan karangannya ditentukan oleh guru (Axford et.al., 2009: 88). Dalam pelaksanaannya guru menjelaskan cara pengarang menulis sebuah tulisan yang digunakan sebagai model. Berdasarkan pengertian ini, model ini berbeda dengan model menulis lainnya yang seluruh perencanaan menulis diserahkan kepada siswa. Dalam model ini perencanaan menulis dijelaskan guru sehingga tulisan yang dihasilkan dari kegiatan pembelajaran ini lebih bersifat tulisan rekonstruksi. Siswa hanya akan meniru apa yang dilakukan penulis teks yang dijadikan model. Tujuan utama model ini adalah agar siswa mengetahui bagaimana sebuah karangan dibuat berdasarkan pengimajinasian, pemikiran, dan pengemasan yang dilakukan pengarang.

\section{Model Menulis Kolaborasi}

Model menulis kolaborasi merupakan model pembelajaran menulis yang memanfaatkan pengalaman penyusunan karangan secara bersama-sama sebagai dasar bagi penyusunan karangan secara mandiri. Berdasarkan pengertian ini menulis kolaborasi diawali dengan kegiatan menulis secara bersama-sama melalui kegiatan urun rembuk ide dan diakhiri dengan menulis secara mandiri. Tujuan utama model ini adalah memberikan pengalaman pada siswa bagaimana menyusun sebuah karangan. Berdasarkan pengalamannya tersebut, siswa diharapkan dapat menentukan langkah-langkah menulis, pola menulis, dan gaya penulisan sebuah karangan. Selanjutnya siswa diharapkan mampu menulis secara mandiri.

Demikianlah enam model pembelajaran menulis yang diyakini akan mengembangkan kemampuan siswa menulis sekaligus membangun karakter siswa. Model-model pembelajaran menulis yang lain tentu saja masih banyak. Selain itu, guru dapat secara kreatif menyusun sendiri model atau metode pembelajaran menulis berdasarkan aktivitas pada setiap tahapan proses menulis yang disajikan dalam buku ini. 


\section{H. Penutup}

Menulis pada dasarnya merupakan sebuah proses sehingga pembelajaran menulis pun harus merupakan sebuah proses yang dilalui siswa agar mampu menulis. Dalam prosesnya, pembelajaran menulis hendaknya diarahkan pada upaya membina kemampuan siswa untuk menulis berbagai genre tulisan untuk berbagai tujuan, berbagai sasaran baca, dan berbagai konteks sosial budaya. Sejalan dengan tuntutan ini, pembelajaran menulis selayaknya dikemas melalui penciptaan sejumlah aktivitas-aktivitas aktif kreatif yang harus dilakukan siswa selama pembelajaran. Melalui aktivitasaktivitas inilah siswa akan secara tidak sadar menunjukkan karakter dirinya. Aktivitas aktif kreatif ini juga jangan hanya yang bersifat mereproduksi tulisan melainkan harus lebih terarah pada proses produksi tulisan yang asli dan memiliki daya kreativitas yang tinggi.

\section{DAFTAR PUSTAKA}

Akhadiah, S. (1999) Pembinaan Kemampuan Menulis. Jakarta: Erlangga.

Axford, B. et.al. (2009) Scaffolding Literacy. Australia: ACER Press.

Brown, H.D (2001). Teaching By Principle: An Interactive Approach to Language Pedagogy. San Francisco: Longman.

Cox, C. (1999). Teaching Language Arts: A Student-and Response-Centered Classroom. Boston: Allyn and Bacon

Dorn, L.J. \& Soffos, C.( 2001) Scaffolding Young Writers: A Writers Worshop Approach. Portland: Stenhouse Publishing.

Gie, T.L. (2002) Terampil Menulis. Yogyakarta: Andi Offset.

Macken, M. et,al, (1990) A Genre-Based Approach to Teaching Writing. Australi: Literacy\&Education Research Network.

Sorenson, S. (2010) Webster's New World Student Writing Handbook. Fifth Edition. Canada: Wiley Publishing.

Sundem, G. (2007) Improving Student Writing Skills. California: Shell Education.

Tompkins dan Hoskisson (1991). Language Arts: Content and Teaching Strategies. New York: Maxwell.

\section{BIODATA PENULIS}

Yunus Abidin adalah dosen Universitas Pendidikan Indonesia dpk. UPI Kampus Cibiru. Penulis menyelesaikan pendidikan jenjang magister (S2) dari Sekolah Pascasarjana UPI Bandung. 
